\title{
DETERMINATION OF THE TRANSMISSIVITY OF A KARSTIFIED AQUIFER FROM MINE DEWATERING DATA
}

\author{
${ }^{1}$ Gyöngyi KARAY, ${ }^{2}$ Mariann SZILÁGYI, ${ }^{3}$ Géza HAJNAL \\ ${ }^{1,3}$ Department of Hydraulic and Water Resources Engineering, Faculty of Civil Engineering \\ Budapest University of Technology and Economics, Müegyetem rakpart 3, H-1111 Budapest \\ Hungary, e-mail: ${ }^{1}$ karay.gyongyi @ epito.bme.hu, ${ }^{3}$ hajnal.geza@epito.bme.hu \\ ${ }^{2}$ MSc-Student, Faculty of Civil Engineering, Budapest University of Technology and \\ Economics, Müegyetem rakpart 3, H-1111 Budapest, Hungary, \\ e-mail: szilagyi.mariann@outlook.com
}

Received 18 December 2015; accepted 4 July 2016

\begin{abstract}
The forty years of intensive mine dewatering in the Transdanubian Range contributed to getting high quality and large amount of data about the karstified aquifers, which could not be gained in any other way. In addition to providing the claimed depression to the safety mining under the original karst water level, the scientific investigation of the processes was emphasized. Although the mines were abandoned the data sets could be a great base of additional investigation about the karstified aquifers. This paper presents the evaluation of dewatering data as pumping test data by using many methods.
\end{abstract}

Keywords: Karst aquifer, Mine dewatering, Evaluation of pumping tests, Kazemi's method, Moench's method

\section{Introduction}

The karstified aquifers in Hungary have a very significant role. Approximately $20 \%$ of the country's area is underlain by water soluble rocks, which can form karst and $25 \%$ of the drinking water come from karst aquifers [1]. The largest continuous area covered by soluble rocks is the Transdanubian Range, which lies over a distance of $270 \mathrm{~km}$ on the right side of the Danube. This system of mountains was the location of the almost fifty-year-long fight between the mining industry and the karst water.

In the 1940-50s the level of the exploitation of brown coal and bauxite reached the karst water table. As a result of the following mining works under the groundwater table water inrush occurred in the mines and active and passive lowering of the water table became necessary. The construction of dewatering systems was foregone by some 
hydrogeological investigations of the rocks and more measurements were carried out during the operation of this system. Due to the fact that the mines were closed suddenly in the 1990s, furthermore due to arguments surrounding this event, the huge amount of measurement data was not fully developed.

The highest discharge rate of dewatering system was applied by the bauxite mine of Nyirád (see Fig. 1). The mine located on the western part of the Transdanubian Range, operated from 1939 to 1990 and the exploited amount of water reached 3.8 billion $\mathrm{m}^{3}$ while the amount of bauxite was 40 million tons [2]. The depression of water level exceeded $100 \mathrm{~m}$ and its affect spread to tens of kilometers: the hydraulic head was decreased in the aquifer, which caused the decrease of discharge rate of springs or they even fell dry. The effect of the mining to the decrease of the water temperature and recharge in Hévíz Lake is not completely clarified. However many researchers agreed that the dewatering of mines caused the fall in temperature of the water and the decrease of the recharge in the lake because of the strong hydraulical relationships among the aquifers of the Transdanubian Range. Hydrogeological surveys were made since 1957 and a large dataset consists of water levels in wells, discharge rates of springs, precipitation data etc. was collected.

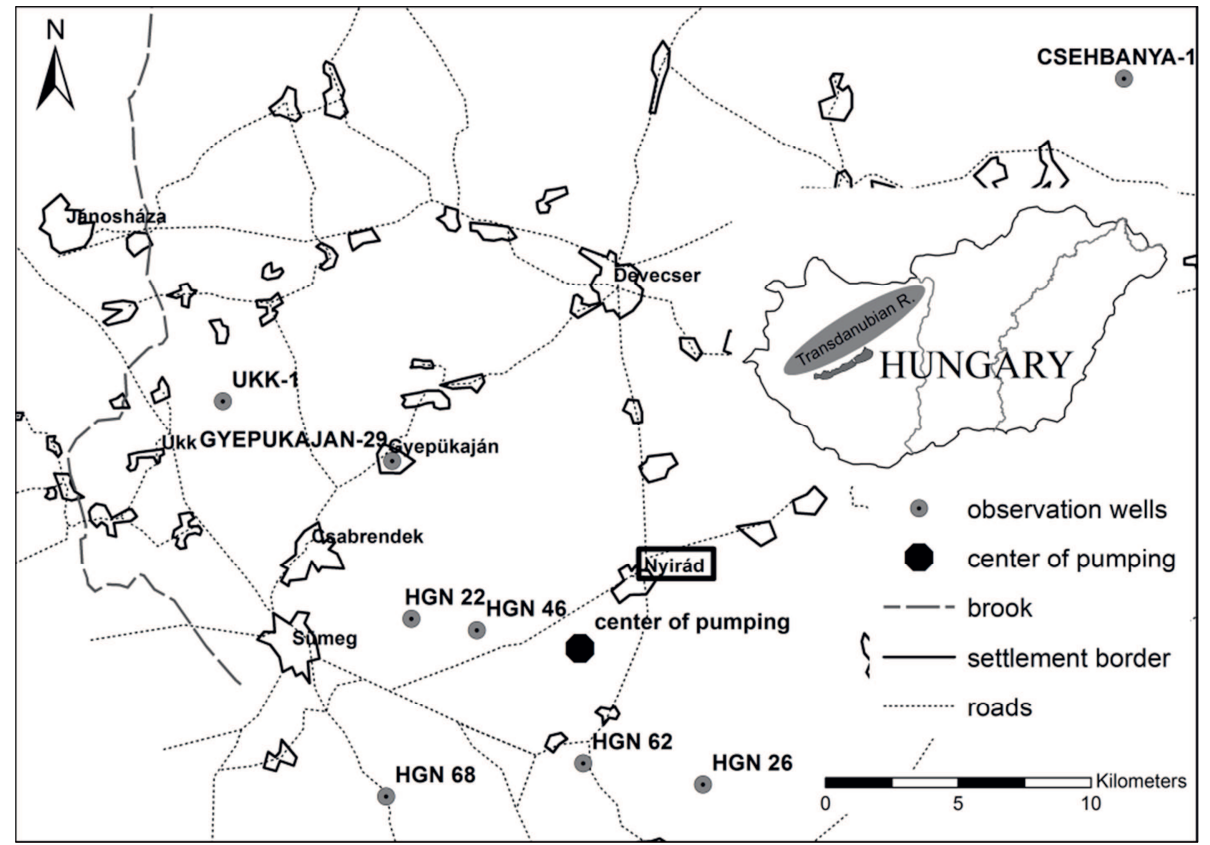

Fig. 1. Location of Nyirád and its surroundings

The advancement and spread of computers allows the analysis of these data in new ways. There are applicable methods, which were further developed but only with computers did they become well usable. The aim of this investigation was the analysis of the applicability of some non-used methods compared to the commonly used 
methods and their previous results. Hence, more information about the hydrogeological characteristic of the Transdanubian Range, more especially the surrounding area of Nyirád can be collected.

\section{Review of the area surrounding Nyirád}

\subsection{Geological settings}

The most important section of the geological settings is the Triassic carbonate succession; the following description is mostly focused on it.

The main amount of the Transdanubian Range is built up by Triassic carbonates developed on the supposedly Silurian-Devonian crystalline bedrock [3]. The 3-4 km thick carbonate sequences were formed along the Neotethys margin [4]. In the Early Triassic mixed shelf sedimentation - dolomite and siliciclastic sediments - was developed during semiarid conditions. These layers were overlaid by shallow marine dolomites and limestones in the Middle Triassic [5]. The Main Dolomite Formation was developed in the Late Triassic, as a result of high-frequency sea level oscillation [3], [4], [5], [6]. The generally arid climate regime is reflected in the extensive dolomitization [7]. The Main Dolomite is 500-600 m thick [8], laminated and characterized by fine microstructure. The gradual increase of humidity resulted in the decrease of dolomitization [5], [9]. In the Late Norian-Rhaetian non-dolomitized carbonate sequences - the Dachstein Limestone Formation - were developed gradually over the dolomitized platform [6]. Both carbonate formations are dissected by faults and are karstified. Partially calcareous, clayey layers developed between the Main Dolomite and Dachstein Limestone during episodically humid climatic conditions [4], [5]. The socalled 'Kössen Layers' are built up by clay, marl, dolomite and limestone cycles [3].

The bauxite lens near Nyirád developed on the surface of the Main Dolomit in Turon, only a few boreholes crossed limestone layers. The bauxite formed more than 200 lenses with 1-30 m thickness in this area between 200 and $-20 \mathrm{~m}$. a. s. 1. (where the sea is the Baltic Sea) [10]. The lenses are covered by Eocene cycles, calcareous or clayey marls, coaly clay lens limestones and nummulites limestones [3].

Leitha limestone and calcareous sandstone developed in the Miocene with 20-25 m thickness. The Miocene layers are often near the surface or partly covered by Sarmatia hydrobia limestone, clay, marl and Pliocene sand [8].

\subsection{Hydrogeological properties}

The Nyirád Basin, the area of the previous bauxite mining, hydraulically belongs to the Bakony Mountains. The karstified Triassic carbonate platform as the mainly confined, partly unconfined aquifer of the basin, is directly connected to the continuous main karst water of the Transdanubian Range [10], [11], which also means that the local dewatering caused regional decrease in the water table level. The upper layers above the carbonate rocks are often aquifers. The rocks suffered intense tectonic movements, which caused permeable fault zones. The hydraulic conductivity of the Triassic layer is assumed to be $10^{-3}-10^{-4} \mathrm{~m} / \mathrm{s}(86.4-8.64 \mathrm{~m} / \mathrm{d})$ [12], the results of early pumping tests 
were between $10^{-2} \mathrm{~m} / \mathrm{s}$ and $10^{-9} \mathrm{~m} / \mathrm{s}\left(864-8.64 \times 10^{-4} \mathrm{~m} / \mathrm{d}\right)$ and the value used for the planning of dewatering system was $7 \times 10^{-5} \mathrm{~m} / \mathrm{s}(6.05 \mathrm{~m} / \mathrm{d})[10]$.

The water amount in karstified rocks is from the static and dynamic water sources. The static source, which does not have a natural water recharge and is stored in fractures, voids, pores and karst conduits, totals 29.3 billion $\mathrm{m}^{3}$ in volume in the Transdanubian Range. The renewable dynamic source, the permanently supplied water amount by precipitation and infiltration, is $777600 \mathrm{~m}^{3} / \mathrm{d}[13]$.

\subsection{Bauxite mining below the karst water table}

Since 1939 the mining of bauxite in the Nyirád Basin went on but only in the 1950s did the mine-shafts reach the level of the main karst water. The first water inrush occurred in 1950 with $7200 \mathrm{~m}^{3} / \mathrm{d}$ discharge rate in the Táncsics mine on the level of 176.5 m.a.s.l, which was by this time above the average main karst water level. Six years later a $24480 \mathrm{~m}^{3} / \mathrm{d}$ discharge flooded a mine-shaft, which clarified that the mining works could not be continued with passive methods of water protection [2]. Based on preliminary studies of the aquifer, an active water table lowering system was planned. The very high discharge rate of the inrush water allowed the building of a dewatering system from large-diameter pumping wells. Between 1966 and 1988, 44 dewatering wells were constructed. The amount of the pumped water increased rapidly, the discharge rate of the dewatering systems of all mines in the Transdanubian Range reached the natural supply of karst water until 1970 [2]. Originally the planned discharge of the pumped water in the mine of Nyirád was $57600 \mathrm{~m}^{3} / \mathrm{d}$ but this rate had already been exceeded in 1963 and the highest value was $460800 \mathrm{~m}^{3} / \mathrm{d}$ in 1978 [14].

Karst water monitoring started in 1957 when the Hydrogeology Division of the Bauxite Exploration Company was founded [2]. Discharge rates of springs and water level in observation wells were measured. Springs and brooks were detected, which since went dry (Szentkút 1963, Kinder Lake 1970, Lesence and Világos Brook 1970, Egervíz 1975) [14]. Many researchers agreed that the decreasing discharge and temperature of the spring of Lake Hévíz was also caused by the mine dewatering of Nyirád [14]. The pumped discharge was moderately decreased in the 1980s but the water level was still lowering [2]. The original water level was at 176 m.a.s.l. and it lowered by more than $100 \mathrm{~m}$. A part of the pumped water was used in the water supply even after abandoning the mines in 1990. After stopping the active dewatering of mines the karst water level started to increase, the effect of the minor discharge $\left(72000 \mathrm{~m}^{3} / \mathrm{d}\right)$ of the water supply was not remarkable. The original water level has presumably not been reached yet.

\section{Applied methods}

Four evaluation methods for pumping tests were applied to analyze data from mine dewatering. The Thiem's and Theis's method are widely used, simple and well-usable methods. These traditional methods were used previously to determine the parameters of the aquifers near Nyirád [10]. However, both methods assume homogeneous and isotropic aquifers. Nevertheless, they are often used in practice to evaluate data from 
fractured aquifers. Moreover, two methods developed for fractured aquifers were also used. The Kazemi's method is a quite simple method with only several parameters to evaluate data from observation wells. It is an advanced version of many previous methods and its results approach well results from other methods for fractured rocks [15]. The Moench's method is a procedure for fractured rocks which is used in practice; it takes into account many effects which are neglected by other methods. Both methods for fractured aquifers were chosen from the many known methods to avoid the incorrect theoretical backgrounds (e. g. water flows into the well only from the fractures).

\subsection{Thiem's method}

The simplest method to evaluate pumping tests is the Thiem's or Dupuit-Thiem's method, which assumes steady-state flow [16], [17]. These methods assume homogeneous, isotropic aquifers with uniform thickness and infinite extension and a constant discharge rate from the fully penetrated well. Thiem's method was developed for confined and the Dupuit-Thiem's method for unconfined aquifers but these two methods are identical if the drawdown is not large compared to the aquifers' original saturated thickness [18]. In this case the transmissivity of the aquifer can be calculated. For the relevant equations see [16].

The steady state condition rarely occurs but if the difference between drawdown in two different observation wells is constant, the so-called transient steady-state flow is reached and the method is applicable [15].

In case of more than one observation well the transmissivity could be calculated with the help of a straight line drawn on $\log \left(r_{i}\right)-s_{i}$ points.

\subsection{Theis's method}

The well-known Theis's method was developed to evaluate pumping tests in confined homogeneous, isotropic aquifers with uniform thickness and infinite extension under unsteady-state flow condition [19]. The discharge rate should be constant and the well should penetrate the aquifer in its entire thickness [15], [17]. The Theis's equation is presented in [19].

There is also a straight line method of Theis, where the recovery data are plotted on against $t / t$ ' (time since the pumping started versus time since the pumping ended). These data on semi-log representation should fit to a straight line. From the slope of the straight line the transmissivity can be calculated.

\subsection{Kazemi's method}

The idealization of homogeneity and isotropy is rarely valid but usually well usable. However, the fractures and karst conduits strongly influence the groundwater flow, therefore, the Theis's method and the others developed for homogeneous aquifer might not describe the flow well [20]. Hence, new methods were developed based on the Barenblatt et al.'s double-porosity theory to evaluate pumping tests in fractured rocks [21]. One of them is Kazemi et al.'s method developed for observation wells [22], [23]. 
The basic assumptions are that the aquifer is confined with infinite areal extent and uniform thickness, the discharge rate of the fully penetrated pumping well is constant and the fracture system is a three-dimensional orthogonal system. Apart from the transmissivity and storativity of rock matrix and fractures two additional dimensionless parameters are taken into account to describe the aquifer. The first parameter $(\omega)$ is the ratio of the storativity of the fractures to the total storativity, and the second parameter ( $\lambda$ ) describes the inhomogeneity of the fractured rock [24].

According to these parameters the drawdown in the observation well is:

$$
s(r, t)=\frac{Q}{4 \cdot \pi \cdot T_{f}} F\left(u^{*}, \lambda, \omega\right)
$$

where

$$
u^{*}=\frac{T_{f} t}{\left(S_{f}+\beta S_{m}\right) r^{2}}
$$

where $s$ is the drawdown measured at a distance $r$ from the pumping well at the time of $t$ [L]; $Q$ is the constant well discharge $\left[\mathrm{L}^{3} / \mathrm{T}\right] ; T_{f}$ is the transmissivity of the fractures $\left[\mathrm{L}^{2} / \mathrm{T}\right] ; T_{m}$ is the transmissivity of the rock matrix $\left[\mathrm{L}^{2} / \mathrm{T}\right] ; S_{f}$ is the storativity of the fractures [-]; $S_{m}$ is the storativity of the rock matrix [-]; $\beta$ is a factor, for early time analysis it equals zero and for late-time analysis it equals $1 / 3$ or $1[-]$; and function $F$ contains exponential integrals of $u^{*}, \omega$ and $\lambda$.

\subsection{Moench's method}

Moench developed his method according to two different idealizations of fracture system geometry. The Moench's solution assumes, in addition to the assumption of the Kazemi's method a finite-diameter well with wellbore storage and skin effect and a regular fracture system among slab-shaped or spherical blocks with fracture skin effect [25]. The method uses many parameters and equations. Only their simplified version is presented here for slab-shaped blocks.

The Laplace transform solution for dimensionless drawdown in an observation well is:

$$
h_{B, D}=\frac{2 K_{0}\left(r_{D} x\right)}{p\left\{p \cdot W_{D}\left[K_{0}(x)+x \cdot s_{w} \cdot K_{1}(x)\right]+x \cdot K_{1}(x)\right\}},
$$

where

$$
x=f\left(q_{D}, r_{w}, b^{\prime}, T_{m}, T_{f}, S_{s, m}, S_{s, f}, p, s_{f}\right),
$$


and $K_{i}$ is the modified Bessel function of second kind, $i$-th order; $r_{D}$ is the ratio of the radial distance between pumping and observation well and the radius of the pumping well [-]; $p$ is the Laplace transform variable; $W_{D}$ is the wellbore storage factor $[-] ; s_{w}$ is the skin factor of the well [-]; $q_{D}$ is the source term [-]; $r_{w}$ is the well radius [L]; $b$ ' is the half of the block thickness [L]; $S_{S, m}$ is the specific storage of the rock matrix [1/L]; $S_{S, f}$ is the specific storage of the fractures $[1 / \mathrm{L}] ; s_{f}$ is the skin factor of the fractures [-].

\section{Results}

During the operation of mines many water level measurements were done. The collected data are not fully prepared [2] and even the development of numerical methods can be used for advanced analysis. The operation of the dewatering system is similar to a group of pumping wells and the karst level observations can be used as data from observation wells. This analogy allows the evaluation of data as pumping test data.

As a long-term pumping test, the results of the analysis of the mine dewatering system lead to get hydraulic properties of the affected aquifer. Defining the widely used representative element volume, the smallest sample size in which the highly variable properties (e.g. porosity, density, hydraulic conductivity) can be averaged into single properties representing the whole rock mass is generally not possible in karst aquifers [26], which also means that the specification of the properties can be more difficult than in a porous media. However, each volume, which is higher than the representative element volume has the same properties according to the theory. Considering all above described theories it can be reasonably assumed that the aquifer affected by the minedewatering with its more than 50 billion $\mathrm{m}^{3}$ volume represents acceptable average hydraulic properties of the aquifer of the Nyirád Basin.

The group of the pumping wells was replaced with one well because of the discharge rate time-series are not known for each well. A new well located in the center of the well group ensured the whole amount of pumped water with different discharge rate. The radial distance of the observation wells was calculated from this well.

Data from eight observation wells were used for the analysis: HGN 22, HGN 26, HGN 46, HGN 62, HGN 68, Csehbánya-1 (CSB), Ukk-1 (U), ), Gyepükaján-29 (GYK) (see Fig. 1). Only the recovery data are available at the GYK well. The available database included 24-49-year-long time-series. The needed information and data sets was ensured by the Transdanubian Regional Waterworks Corporation and the CentralTransdanubian Directorate of Water Management.

Each used method was originally developed for confined aquifers. The study area is built up by karstified aquifers; the Main Dolomite is partly covered by younger carbonate rocks. This means that the groundwater is under atmospheric pressure but the behavior of the aquifer during the pumping test is not similar to a traditionally interpreted unconfined aquifer. The delayed water table response is missing in every observed time-series; the intermediate segment of the displacement-time curves of an unconfined aquifer caused by the falling water table is missing. Moreover, the saturated thickness is much higher than the displacement of the water table. In this case the difference between unconfined and confined solutions could be neglected [15]. 


\subsection{Thiem's method}

To plan the active dewatering system some simple methods of evaluating pumping tests were used [10]. To make the calculations in this paper comparable with the further results the transmissivity was calculated in two different times of pumped period to get more detailed results. The discharge rate data were averaged and a rate of $288000 \mathrm{~m}^{3} / \mathrm{d}$ was used for calculations. Based on the known distance from the idealized pumping well and the drawdown data in two different times, the transmissivity can be calculated. 21 possible combinations of wells can be used but only 6 combinations resulted acceptable values both times. Any combination with CSB and U wells did not work; which can be the result of their huge distance from the pumping well.

The acceptable results moved around two different values; for more detailed data see Table I, where $T$ is the transmissivity of the aquifer $\left[\mathrm{L}^{2} / \mathrm{T}\right]$.

Table I

Results of the Thiem's method

\begin{tabular}{|l|c|c|c|}
\hline & Thiem 1 & Thiem 2 & Thiem straight line \\
& $T\left(\mathrm{~m}^{2} / \mathrm{d}\right)$ & $T\left(\mathrm{~m}^{2} / \mathrm{d}\right)$ & $T\left(\mathrm{~m}^{2} / \mathrm{d}\right)$ \\
\hline Average & 303 & 684 & 310 \\
Standard deviation & 16 & 78 & - \\
\hline
\end{tabular}

\subsection{Theis's method}

The time-drawdown curves of the observation wells were fitted to the theoretical curves calculated by minimizing the sum of squares of differences between calculated and measured drawdown. The results of the calculation are shown in Table II and an example of curve fitting is in Fig. $2 a$. In the case where the required fitting was not reached with the use of the whole time series, only the drawdown data were analyzed (see $4^{\text {th }}$ column in Table II). The averaged transmissivity is acceptable; the standard deviation is quite small. To improve the results the very different data of HGN 26 well was omitted from the average. In Table II, $S$ [-] is the storativity.

Table II

Results of the Theis's method

\begin{tabular}{|c|c|c|c|c|c|c|}
\hline & \multicolumn{2}{|c|}{ Theis's method } & \multicolumn{2}{|c|}{ Theis's recovery } & \multicolumn{2}{|c|}{ Theis's drawdown } \\
\hline & $T\left(\mathrm{~m}^{2} / \mathrm{d}\right)$ & $S(-)$ & $T\left(\mathrm{~m}^{2} / \mathrm{d}\right)$ & $S / S^{\prime}(-)$ & $T\left(\mathrm{~m}^{2} / \mathrm{d}\right)$ & $S(-)$ \\
\hline HGN 22 & \multirow[t]{2}{*}{868} & \multirow[t]{2}{*}{0.020} & 697 & 1.59 & \multirow{3}{*}{1556} & \multirow{3}{*}{0.135} \\
\hline HGN 26 & & & 1497 & 2.16 & & \\
\hline HGN 46 & 871 & 0.045 & 879 & 1.01 & & \\
\hline HGN 62 & \multirow[t]{3}{*}{794} & \multirow[t]{3}{*}{0.045} & 717 & 1.50 & \multirow{4}{*}{$\begin{array}{l}880 \\
830\end{array}$} & \multirow{4}{*}{$\begin{array}{c}0.045 \\
0.0026\end{array}$} \\
\hline HGN 68 & & & 965 & 1.83 & & \\
\hline CSB & & & 514 & 2.23 & & \\
\hline $\mathrm{U}$ & 868 & 0.0031 & 728 & 1.49 & & \\
\hline GYK & \multicolumn{2}{|c|}{ only recovery data } & 680 & 2.60 & \multicolumn{2}{|c|}{ only recovery data } \\
\hline Average & 850 & 0.028 & 740 & 1.54 & 855 & 0.024 \\
\hline S. deviation & 38 & 0.021 & 146 & 0.85 & 35 & 0.030 \\
\hline
\end{tabular}




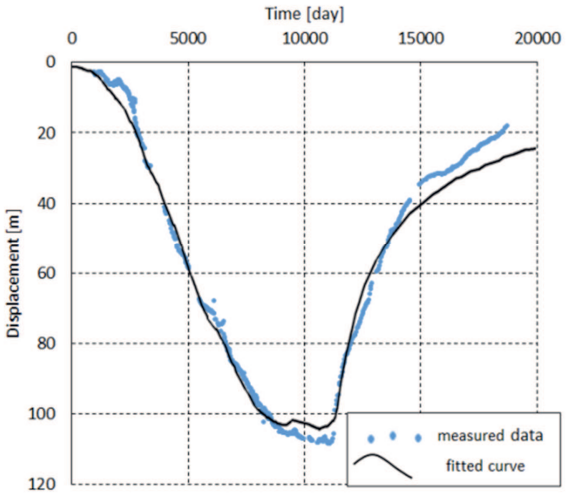

a)

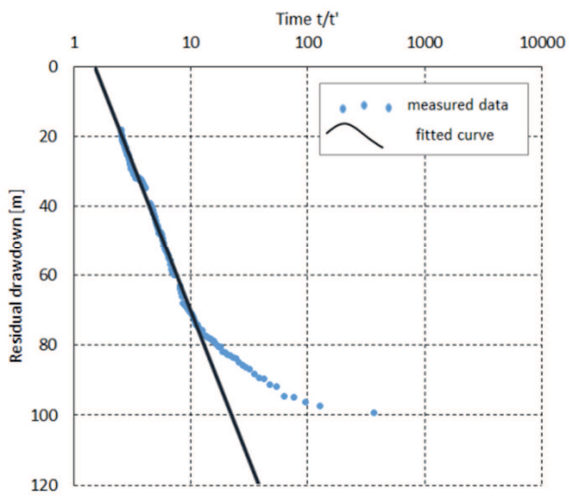

b)

Fig. 2. a) HGN 22 - Evaluation by Theis's method;

b) HGN 22 - Evaluation by Theis's recovery method

In the Theis's recovery method a straight line was fitted to the data. The S/S' (storativity during pumping versus storativity during recovery) should be around 1 according to the theory but in this case it was higher (see Table II and Fig. 2b). The assumption of the change of the storativity is not quite justified with these data. To establish this change more analysis is required.

\subsection{Kazemi's method}

After the substitution of each above mentioned parameters in Eq. (1) only four parameters are left, which have to be determined by curve fitting: $T_{f}, T_{m}, S_{f}$, and $S_{m}$. Additional efforts were needed to determine $\beta$; its value is 0 at the early pumping times and 1 in later times. To fulfill this criterion a cosine function was used to give the value of $\beta$ each day [15]. To calculate $\alpha$, the thickness of one block was assumed to be $0.01 \mathrm{~m}$. During the analysis it was discovered that $\alpha$ and $T_{m}$ always appeared as the multiplication of each other. If this multiplication is constant the calculated curve does not change even if the values of $\alpha$ or $T_{m}$ are modified; so the effect of these two parameters could not be analyzed separately. Only the drawdown data were used.

The results showed that the fitted curve was not sensitive to the parameters of the rock matrix $\left(\alpha T_{m}=10^{-6}-10^{-12} \mathrm{~m} / \mathrm{d}, S_{m}=1-10^{-4}\right)$. Although the transmissivity of the fractures could be in an acceptable range, the standard deviation of the storativity is too high (see Table III). The fitting is not as proper as it was required at HGN 62, CSB and $\mathrm{U}$ wells. The fitted and measured data started to trend afar from each other and the calculated curve is not smooth enough (Fig. 3a). 
Table III

Results of the Kazemis's method

\begin{tabular}{|l|c|c|}
\hline & $T_{f}\left(\mathrm{~m}^{2} / \mathrm{d}\right)$ & $S_{f}(-)$ \\
\hline HGN 22 & 1500 & 0.010 \\
HGN 26 & 3200 & 0.100 \\
HGN 46 & 1700 & 0.010 \\
HGN 62 & 1700 & 0.010 \\
HGN 68 & 2900 & 0.010 \\
CSB & 2200 & 0.001 \\
U & 1000 & 0.010 \\
\hline Average & 2029 & 0.022 \\
Standard deviation & 787 & 0.035 \\
\hline
\end{tabular}

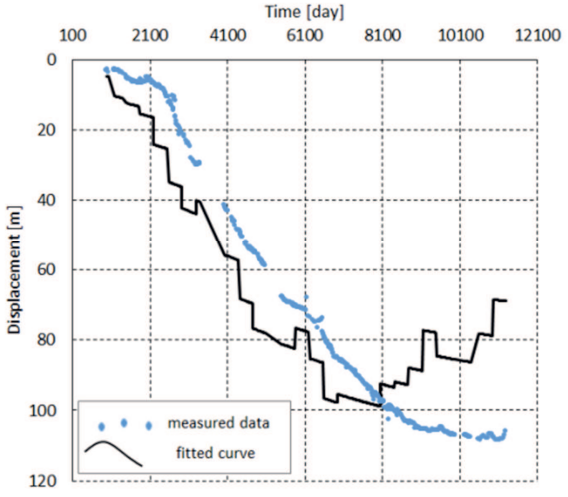

b)

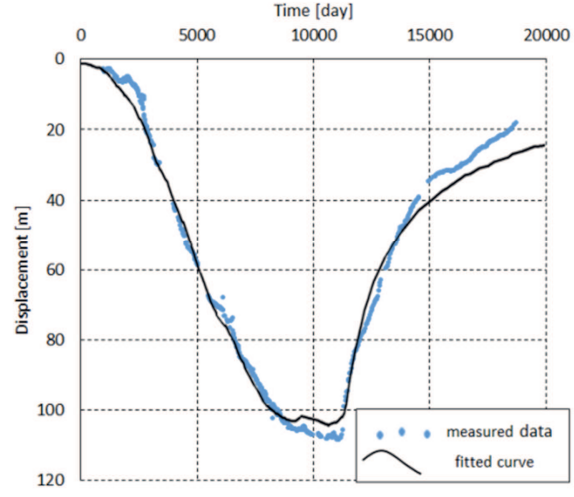

b)

Fig. 3. a) HGN 22 - Evaluation by Kazemis's method;

b) HGN 22 - Evaluation by Moench's method

\subsection{Moench's method}

In the Moench's method six unknown parameters had to be determined by the means of curve fitting: $T_{f}, T_{m}, S_{s, f}, S_{s, m}, s_{w}$ and $s_{f}$. The slab-shaped idealization was used because it resulted a much better fit than the spherical idealization; the thickness of one block was $0.01 \mathrm{~m}$. The evaluation of data of seven wells resulted in that the calculated curves are sensitive neither to the skin values $\left(s_{w}\right.$ between -5 and 10 and $s_{f}$ between 0 and 10) nor to the transmissivity of the rock matrix (between $10^{-11}$ and $10^{-1} \mathrm{~m}^{2} / \mathrm{d}$ ). Moreover, a relationship between the two specific storage data was discovered: the effect of increasing one of them could be compensated by decreasing the other one. Based on these discoveries only the transmissivity results of the fractures could be acceptable. However a suitable pair of specific storage data was showed in Table IV beside the transmissivity values and Fig. $3 b$ shows the fitting of the measured and calculated curves of the HGN 22 well. 
Table IV

Results of the Moench's method

\begin{tabular}{|l|c|c|c|}
\hline & $T_{f}\left(\mathrm{~m}^{2} / \mathrm{d}\right)$ & $S_{s, f}(1 / \mathrm{m})$ & $S_{s, m}(1 / \mathrm{m})$ \\
\hline HGN 22 & 881 & $1.2 \times 10^{-6}$ & $6.4 \times 10^{-5}$ \\
HGN 26 & 1643 & $1.7 \times 10^{-4}$ & $2.5 \times 10^{-4}$ \\
HGN 46 & 899 & $1.8 \times 10^{-5}$ & $1.2 \times 10^{-4}$ \\
HGN 62 & 715 & $8.9 \times 10^{-5}$ & $1.1 \times 10^{-4}$ \\
HGN 68 & 869 & $1.3 \times 10^{-4}$ & $1.4 \times 10^{-4}$ \\
CSB & 662 & $4.6 \times 10^{-6}$ & $5.0 \times 10^{-6}$ \\
U & 869 & $2.9 \times 10^{-6}$ & $7.0 \times 10^{-6}$ \\
GYK & 253 & $4.4 \times 10^{-5}$ & 1.00 \\
\hline Average & 934 & $6.0 \times 10^{-5}$ & $2.1 \times 10^{-4}$ \\
Standard deviation & 326 & $7.1 \times 10^{-5}$ & $2.5 \times 10^{-4}$ \\
\hline
\end{tabular}

The GYK well has only recovery data, and their evaluation led to different results. The calculated curve was sensible to every parameter so the resulted values were not used for further analysis because of their individuality. These data might be compared to other recovery data.

The transmissivity value at the HGN 26 well is much higher than the average. Without this value the averaged transmissivity of fractures would be $816 \mathrm{~m}^{2} / \mathrm{d}$ with a standard deviation of $101 \mathrm{~m}^{2} / \mathrm{d}$.

This method is used in practice [27].

The importance of evaluating dewatering data is clear: a better knowledge helps to find a safe method for the water supply [28], it can contribute to the numerical modeling, [29] which is also an effective tool to investigate aquifers, and last but not least, it helps to preserve our underground water resource.

\section{Conclusions}

Drawdown and recovery data from eight wells were analyzed with four different methods. In general the storage data were not accurate enough except of the results of the Theis's method. However, the transmissivity data are well conditioned and comparable. The orders of magnitude of the calculated transmissivity results were quite similar, especially when it is taken into account that the transmissivity of the fractures is only a part of the transmissivity of the aquifer. The previously estimated parameters had to be multiplied by the thickness of the aquifer (it is roughly between 100 and $2000 \mathrm{~m}$ ); the resulted values $\left(605-17280 \mathrm{~m}^{2} / \mathrm{d}\right)$ are quite similar to the calculated data in this paper.

The lowest results of transmissivity were received by the Thiem's method but the assumption of steady state flow was not fulfilled, so the result can be accepted as a fast and approximated value for the order of magnitude of the transmissivity. The Theis's and Moench's methods resulted in very similar transmissivity even if only the transmissivity of the fractures was calculated by the Moench's method. The Kazemi's method yielded the highest results for the transmissivity of the fractures; it fits the required result according to the double porosity theory but does not fit the data 
calculated with the other method for fractured aquifers. Perhaps the fitting of Kazemi's curves could be improved to reach values with lower deviation.

Both methods for fractured aquifers showed that the results are not sensitive to the transmissivity of the rock matrix. It is caused by the low thickness of blocks and the results became more sensitive when the thickness was increased.

The analysis of curve fitting yielded quite same results in each method. In the first 2000 days the calculated curves overestimated the drawdown, the measurements show a slower increase of the drawdown. Perhaps, the discharge data is an averaged value so the calculations could not take into account the change of the discharge within a year. The wellbore-storage can also influence the calculations in this direction in a short period. The middle section of the pumping resulted good fitting between measured and calculated data and parallel curves by Kazemi's method. The Kazemi's method does not take into account a still unknown effect which resulted that the best fitting is the previously mentioned parallel one. The late drawdown measurements are often under the calculated data, which can show the change of the boundary conditions. This assumption is supported by the recovery section where the fitting is not very good. The results of the Theis's recovery method show that the storativity during pumping and after pumping should be different; the water level increase was faster than the estimated one. During the long pumped and observed periods the boundary conditions could change, the closing of every mine in the Transdanubian Range can also cause a faster recovery, and there can also be irreversible alterations in rock mass (e.g. the closing of micro-fissures because of the decrease in pressure, opening new recharge paths, both caused by the intensive dewatering).

These calculations showed that the simplified methods are usable to estimate hydraulic properties of a fractured aquifer. To get acceptable results more effort is needed by using the methods developed for fractured aquifers. However their usage could lead to a better understanding of fractured aquifers.

\section{Acknowledgements}

Special thanks are given by the authors to the Transdanubian Regional Waterworks Corporation and the Central-Transdanubian Directorate of Water Management for the data service and thanks to Vilmos Vasvári and Ivett Vajda for their helpful cooperation.

\section{References}

[1] Eördöghné Miklós M. Characteristics of the aquifer from the perspective of the water services, Pollack Periodica, Vol. 9, No. 1, 2014, 113-120.

[2] Böcker T. Bauxite - mine - water, (in Hungarian) Bányászati és Kohászati Lapok, Bányászat, Vol. 140, No. 6, 2007, pp. 43-46.

[3] Szentes F., Barnabás K., Czabalay L., Dek M., Dér I., Jugovics L., Knauer J., Kopek G., Kókay J., Majoros Gy., Marczel F., Noszky J., Szabó I., Szűcs L. Memoir to the geological maps of Hungary, 1:200, 000, (in Hungarian) L-33-XII, Veszprém, Geological Institute of Hungary, Budapest, 1972. 
[4] Haas J., Lukoczki G., Budai T., Demény A. Genesis of upper Triassic peritidal dolomites in the Transdanubian Range, Hungary, Facies, Vol. 61, No. 3, 2015, pp. 1-28.

[5] Haas J., Budai T., Raucsik B. Climatic controls on sedimentary environments in the Triassic of the Transdanubian Range (Western Hungary), Palaeogeography, Palaeoclimatology, Palaeoecology, Vol. 353, 2012, pp. 31-44.

[6] Haas J. Characteristics of peritidal facies and evidences for subaerial exposures in Dachstein-type cyclic platform carbonates in the Transdanubian Range, Hungary, Facies, Vol. 50, 2004, pp. 263-286.

[7] Rostási Á., Raucsik B., Varga, A. Palaeoenvironmental controls on the clay mineralogy of Carnian sections from the Transdanubian Range (Hungary), Palaeogeography, Palaeoclimatology, Palaeoecology, Vol. 300, No. 1, 2011, pp. 101-112.

[8] Végh S. Geology of the rhaetian formations of the southern Bakony in Hungary, (in Hungarian) Geol. Hungarica, Vol. 14, 1964, pp. 1-110.

[9] Haas J., Budai T., Demény A. Partial dolomitization of foreslope and toe-of-slope facies of a Carnian carbonate platform, Transdanubian Range, Hungary, Central European Geology, Vol. 57, No. 1, 2014, pp. 1-19.

[10] Farkas S. Hydrogeology of the bauxite deposits of Halimba and Nyirád, (in Hungarian) Földtani Közlöny, Vol. 109, 1979, pp. 548-561.

[11] Goldscheider N., Mádl-Szőnyi J., Erőss A., Schill E. Review: thermal water resources in carbonate rock aquifers, Hydrogeol J, Vol. 18, No. 6, 2010, pp. 1303-1318.

[12] Mádl-Szőnyi J., Tóth Á. Basin-scale conceptual groundwater flow model for an unconfined and confined thick carbonate region, Hydrogeol. J, Vol. 23, No. 7, 2015, pp. 1359-1380.

[13] Böcker T. The current state of the Hungarian karst water investigation (in Hungarian) Vízügyi Közlemények, Vol. 51, No. 4, 1969, pp. 485-498.

[14] Kumánovics Gy. Management of karstic water resources in the Dunántúli-középhegység (Transdanubian Middle Mountain Ranges) (in Hungarian) Vízügyi Közlemények, Vol. 80, No. 2, 1988, pp. 229-244.

[15] Kruseman G. P., de Ridder N. A. Analysis and evaluation of pumping test data, International Institute for Land Reclamation and Improvement, Wageningen, 1994.

[16] Thiem, G. Hydrologische Methoden, Gebhardt, Leipzig, 1906.

[17] De Marsily G., Delay F., Gonçalvès J., Renard P., Teles V., Violette S. Dealing with spatial heterogeneity, Hydrogeol J, Vol. 13, No. 1, 2005, pp 161-183.

[18] Jacob C. E. Notes on determining permeability by pumping tests under watertable conditions, U.S. Geol. Surv. Open. File Rept. 1944.

[19] Theis C. V. The relation between the lowering of the piezometric surface and the rate and duration of discharge of a well using groundwater storage, Trans. Amer. Geophys. Union, Vol. 16, 1935, pp. 519-524.

[20] Le Borgne T., Bour O., De Dreuzy J. R., Davy P., Touchard F. Equivalent mean flow models for fractured aquifers: Insights from a pumping tests scaling interpretation, Water Resour Res, Vol. 40, No. 3, 2004.

[21] Barenblatt G. E., Zheltòv I. P., Kochina I. N. Basic concepts in the theory of seepage of homogeneous liquids in fissured rock, Appl. Math. Mech, Vol. 24, No. 5, 1960, pp. 1286-1303.

[22] Kazemi H., Seth M. S., Thomas G. W. The interpretation of interference tests in naturally fractured reservoirs with uniform fracture distribution, Soc. Petrol. Eng. J, Vol. 246, 1969, pp. 463-472.

[23] De Smedt, F. Analytical solution for constant-rate pumping test in fissured porous media with double-porosity behavior, Transport in Porous Media, Vol. 88, No. 3, 2011, pp 479-489.

[24] Vasvári V. Geohydraulische und bohrlochgeophsikalische Untersuchungen in geklüfteten Grundvasserleitern, Technische Universität, Graz, 2001. 
[25] Moench A. F. Double-porosity models for a fissued groundwater reservoir with fracture skin, Water Resour. Res, Vol. 20, 1984, pp. 831-846.

[26] Stevanović Z. (Ed.) Karst aquifers-characterization and engineering, Springer, 2015.

[27] Muldoon M., Bradbury K. R. Site characterization in densely fractured dolomite: comparison of methods. Groundwater, Vol. 43, No. 6, 2005, pp. 863-876.

[28] Andrássy T., Baroková D. Numerical modeling of groundwater flow close to drinking water resources during flood events, Pollack Periodica, Vol. 11, No. 1, 2016, pp. 43-54.

[29] Kolencsik-Tóth A., Kovács B. Calibration process for groundwater flow model of a river influenced shallow aquifer, Central European Geology, Vol. 58, No. 1-2, 2015, pp. 186-198. 